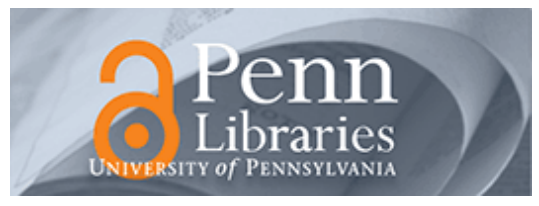

University of Pennsylvania

ScholarlyCommons

Health Care Management Papers

Wharton Faculty Research

2007

\title{
Market Definition in Crude Oil: Estimating the Effects of the BP/ ARCO Merger
}

John Hayes

Carl Shapiro

Robert J Town

University of Pennsylvania

Follow this and additional works at: https://repository.upenn.edu/hcmg_papers

Part of the Business Administration, Management, and Operations Commons, Organizational Behavior and Theory Commons, and the Risk Analysis Commons

\section{Recommended Citation}

Hayes, J., Shapiro, C., \& Town, R. (2007). Market Definition in Crude Oil: Estimating the Effects of the BP/ ARCO Merger. The Antitrust Bulletin, 52 (2), 179-204. Retrieved from https://repository.upenn.edu/ hcmg_papers/96

This paper is posted at ScholarlyCommons. https://repository.upenn.edu/hcmg_papers/96

For more information, please contact repository@pobox.upenn.edu. 


\section{Market Definition in Crude Oil: Estimating the Effects of the BP/ARCO Merger}

\section{Disciplines}

Business Administration, Management, and Operations | Organizational Behavior and Theory | Risk Analysis 


\title{
Market Definition in Crude Oil:
}

\section{Estimating the Effects of the BP/ARCO Merger ${ }^{*} \dagger$}

\author{
John Hayes \\ Charles River Associates \\ Oakland, CA \\ jhayes@crai.com \\ Carl Shapiro \\ Haas School of Business \\ University of California - Berkeley \\ shapiro@haas.berkeley.edu \\ Robert Town \\ Graduate School of Management \\ University of California - Irvine \\ rjtown@uci.edu
}

August 2001

\begin{abstract}
On March 31, 1999 Atlantic Richfield (ARCO) agreed to be acquired by British Petroleum (BP) for $\$ 27$ billion. The merger raised a number of antitrust concerns, including whether the merged company would raise the price of crude oil produced on the Alaskan North Slope (ANS). The combined output of the firms exceeded $70 \%$ of total production of ANS crude oil, suggesting that if ANS crude oil were a distinct market the merged firm would possess power over price. We estimate a model of demand for ANS crude oil based on a simple theoretic model of pricing arbitrage to identify the relevant market in which ANS crude oil trades. The dramatic decline in production of ANS crude oil during the 1990s, as the North Slope passed its peak production, provides an excellent natural experiment to assess the effects on prices of declining output. We find no evidence that ANS is a distinct market and argue it is highly unlikely the merged company could have raised the price of ANS.
\end{abstract}

* The authors would like to thank Dan McFadden and Miguel Herce for their comments on this paper and Bryan Patten for his research assistance.

$\dagger$ The authors were retained by BP and ARCO to provide expert economic advice on the competitive effects of this merger. 


\section{Introduction}

On March 31, 1999 Atlantic Richfield (ARCO) agreed to be acquired by British Petroleum (BP) for $\$ 27$ billion. As originally proposed, the merger would create the largest private-sector oil company in the world. The merger also raised a number of potential antitrust concerns, including whether the combined firm would be able to exercise market power over the huge crude oil reserves on the Alaskan North Slope (ANS). This concern was prompted by the substantial shares of ANS crude production controlled by BP and ARCO. At the time the merger was announced, BP and ARCO were the two largest producers of ANS crude oil, with roughly $40 \%$ and $30 \%$ shares of production respectively.

The potential economic significance of this transaction was enormous. At $\$ 30$ per barrel, ANS crude oil production is worth in excess of $\$ 10$ billion annually. In addition, ANS is an important source of crude oil to the western U.S., which is relatively isolated from the rest of the U.S. petroleum distribution system. Approximately $40 \%$ of the crude oil refined on the U.S. West Coast (USWC) is from the North Slope. ${ }^{1}$ Even a modest exercise of market power over ANS crude oil prices is of concern in these circumstances, given the magnitude of the possible effects.

A traditional starting point for assessing whether a merger will create or enhance market power is to delineate the markets relevant for analysis of the transaction. In the BP-ARCO merger, the FTC alleged a number of relevant markets, including a market for ANS. ${ }^{2}$ The FTC further alleged that BP possessed monopoly market power over the price of ANS prior to its announced merger with $\mathrm{ARCO}$, and it was concerned that the merger would eliminate the firm most likely to eliminate or reduce BP's market power in the future. ${ }^{3}$ Estimates of the elasticity of demand for ANS are plainly useful for evaluating these concerns.

In this paper we present econometric estimates of the demand for ANS sold on the USWC. Given the unusually high quality of the data available in the crude oil market, we believe our analysis is of general interest with respect to the exercise of market definition, as well as more specific interest regarding the oil industry.

The logic behind our analysis is based on a simple model of crude oil pricing for refineries located on the USWC. We heavily exploit the fact that ANS production experienced a very significant, exogenous decline during the 1990s, as the North Slope fields passed their peak productivity. As a direct result of declining ANS production, during the 1990s the USWC shifted from a net exporting region of crude oil to a net importing region of crude oil. Throughout the 1980s, total crude production on the USWC exceeded the quantity demanded in that region, rendering the USWC a net surplus region. The price of ANS, and the prices of other

1 Throughout this paper, we follow the industry convention and include the Petroleum Area of Defense District V (PADD V) states of Alaska, Hawaii, California, Arizona, Nevada, Oregon, and Washington in the region we refer to as the U.S. West Coast.

2 Complaint of Federal Trade Commission for a Preliminary Injunction, FTC vs. BP Amoco, p.l.c. and Atlantic Ritchfield Company, U.S. District Court for the Northern District of California, February 4, 2000.

${ }^{3} I d$. 
crude oils produced in the region, were below the "world" crude price during this period, suggesting that crude oils produced on the USWC might trade in a distinct market. Further, as ANS production declined, its price increased, indicating that the ANS demand schedule was downward sloping over some range. Clearly, if the demand for ANS is sufficiently inelastic over the relevant range, the BP-ARCO merger could create or enhance market power. On the other hand, simple economic reasoning suggests that the price of ANS is constrained by an arbitrage relationship between the ANS price and world prices for other grades of crude oil. When this arbitrage relationship is binding, the elasticity of demand for ANS crude oil is extremely high, and ANS is not a relevant market. A key question for analysis of the effects of this merger, therefore, is which regime will govern ANS prices following the BP-ARCO merger.

Our specification of the demand curve for ANS allows the demand curve to have different slopes depending upon whether the import arbitrage condition is binding. Our econometric results indicate that during the latter half of the 1990s, when the USWC was a net importing region, the price of ANS was constrained by the delivered price of imported crude oils. We draw several conclusions from these results. First, ANS is not a relevant antitrust market under the standard test articulated in the DOJ-FTC merger guidelines. ${ }^{4}$ Second, BP does not possess measurable market power over the price of ANS and did not possess such market power during the latter half of the 1990s..$^{5}$ Finally, the merger between BP and ARCO would not cause the price of ANS crude oil to increase. The demand relationship coefficients are estimated using standard instrumental variables (IV) and time-series econometric techniques.

On April 13, 2000 BP and ARCO entered into a consent agreement with the Federal Trade Commission that allowed the merger to proceed after the parties divested themselves of certain assets including ARCO's holdings of ANS reserves. ${ }^{6}$ Our findings indicate that the ANS divestiture was unnecessary to preserve a competitive price for ANS. Since a deal has already been struck between the FTC and BP/ARCO, our findings cannot affect policy in this matter. ${ }^{7}$ Nevertheless, we believe the analysis we present here is of interest beyond the BP/ARCO merger. First, consolidation appears to be an ongoing trend in the oil industry. Within the last few years there have been several large oil industry mergers, including BP's prior acquisition of Amoco, the Exxon-Mobil merger, the Phillips-Tosco merger, the combination of the refining and marketing businesses of Shell, Texaco and Star Enterprises, and the recently announced acquisitions of Texaco by Chevron and UDS by Valero. In this environment, the antitrust authorities are likely to revisit questions regarding the competitive consequences of petroleum mergers, and the methodology we outline here is applicable to other oil industry mergers. Second, this paper characterizes the market process at work in this large and important industry.

${ }^{4}$ Horizontal Merger Guidelines, U.S. Department of Justice and the Federal Trade Commission, issued April 2, 1992, revised April 8, 1997.

5 We did not study whether BP possessed market power over the price of ANS when the USWC was a net surplus region.

6 "FTC Clears Merger of BP Amoco and Atlantic Ritchfield Company," FTC press release, April $13,2000$.

7 The substance of the analysis contained in this paper was presented to the FTC during the merger review process. 
Finally, this paper highlights the ability of economic theory in conjunction with econometrics to provide valuable insights in antitrust analyses. Advances in economic theory and econometrics increasingly contribute to antitrust analyses. Our work provides one example of such a contribution, and this paper can inform similar analyses performed in other industries.

Over the last decade and a half economists have developed empirical methods to estimate demand parameters for market delineation and to estimate the price effect of a given merger directly. Baker and Rubinfeld (1999) review this literature in detail. Of this strain of research, the paper most similar to our own is by Spiller and Huang (1986). ${ }^{8}$ They estimate a reduced form, switching model of U.S. East Coast gasoline prices to determine the geographic scope of the market for gasoline. Inter-city arbitrage conditions bound the prices in a given locale and the econometric regimes are determined by whether the arbitrage conditions are binding. Two cities are considered in the same market if their arbitrage conditions are sufficiently close that prices cannot (substantially) deviate from one city to the other. Our work differs in a number of respects beyond the physical product of interest. First, we estimate the demand for ANS rather than a reduced-form relationship. Thus we use instrumental variables estimation to correct for a possible bias introduced by endogenous regressors. Second, the process that determines when the arbitrage conditions are binding is exogenous and observable in our model. This fact allows us to avoid estimating the more complex switching model used in Spiller and Huang.

The next section of the paper describes the USWC oil and refining industry. The theoretical model and implied econometric approach are outlined in Section III. The results are presented in Section IV, while Section V concludes.

\section{Industry Background}

There are nearly 40 refineries in the West Coast region. Many of these are small refineries that produce specialized products or are located next to inland fields. The bulk of the crude oil processed in the region - more than 80 percent — is refined at 15 large refineries located along the coast. Table 1 lists these major refineries, describes their capacities, and indicates their quantities of crude oil refined.

\section{[Table 1 about here]}

West Coast refineries process crude oil from three principle sources: California fields, imports, and the Alaskan North Slope. During the 1980s, domestic production on the USWC (i.e., California and Alaska) exceeded refinery capacity by a considerable margin. However, the California and Alaska fields are mature, and their production has been steadily declining for the past decade. ANS production peaked in 1988 at about 2 million barrels per day, or 2,000 MBD $^{9}$ and had declined to 1,200 MBD by 1998; California's crude production peaked in 1985 at 1,200 MBD and had declined to $900 \mathrm{MBD}$ by 1998 . Total refinery runs, on the other hand, have been

8 Another closely related paper is by Slade (1986). She estimates the geographic scope of antitrust markets for wholesale gasoline by determining if prices in a pair of cities are causally (in the sense of Granger) linked.

9 Production of ANS is typically measured in thousands of barrels per day, denoted "MBD." 
roughly constant at about 2,550 MBD on the USWC during the past decade (see Table 1). As a consequence of these trends, the USWC moved from net surplus production in the first part of the 1990s to net deficit in the latter part of the decade. Figure 1 illustrates this change and shows that the USWC produced more crude than it consumed until about 1992, was approximately balanced from 1992 through 1996, and moved solidly into net deficit after 1996.

[Figure 1 about here]

Imports of foreign crude oils filled the production shortfall on the USWC and accounted for about one quarter of crude oil consumed on the USWC by the end of the decade. Figure 2 documents the declining share of ANS and California crude oils in USWC refinery consumption and shows the increasing share taken by imported crude oils. One interesting feature of these data is that imports comprised nearly 10\% of USWC consumption during 1989 through 1992, even when USWC production exceeded consumption. These imports are largely "structural imports" that refineries consume in order to achieve desired input characteristics. These imports are a reminder that crude oils are somewhat differentiated, from light to heavy, sweet to sour. The growing import volumes since 1992 comprise a range of crude types that refiners can substitute for ANS and California crude oils.

[Figure 2 about here]

At the time the merger was announced, BP, ARCO, and Exxon-Mobil were by far the largest producers of ANS crude oil, accounting for more than $90 \%$ of ANS production. Both ARCO and Exxon-Mobil are integrated producers, using the bulk of their ANS production in their own refineries. Exxon-Mobil produces about $140 \mathrm{MBD}$ more ANS than it consumes at its Benicia refinery. ${ }^{10}$ It sells this surplus ANS on the merchant market. ARCO became a net purchaser of ANS in the mid 1990s as its production declined below its internal refining needs. ${ }^{11} \mathrm{BP}$ owned no USWC refineries when the merger with ARCO was announced, and it sold all of its ANS production on the merchant market. ${ }^{12}$ Consequently, BP was by far the largest seller of ANS on the merchant market, selling approximately $60 \%$ of the merchant ANS. ${ }^{13}$ In addition, BP was the only firm that regularly shipped ANS off the USWC, giving BP a unique role in determining the price of ANS.

10 Exxon was required to divest its Benecia, California refinery as a condition of its merger with Mobil. Exxon signed a long term ANS supply agreement for the Benecia refinery with Valero, the acquiring company, as part of this sale. In the Matter of Exxon Corporation and Mobil Corporation, Decision and Order, File No. 991-0077, November 30, 1999.

11 For this reason, the BP-ARCO merger raised some interesting economic issues about the proper analytical treatment of "captive capacity," i.e., capacity used internally by a vertically integrated firm, as distinct from capacity used to sell to the merchant market. We do not explicitly explore these issues in this paper.

12 BP has not owned any refinery assets on the USWC since 1993, when it sold its Ferndale, Washington refinery to Tosco.

13 Pursuant to its consent decree with the FTC, BP divested ARCO's ANS production and is no longer a net seller of ANS. 


\section{Conceptual Framework and Econometric Methods}

Both common sense and casual empirical observation suggest that ANS prices on the USWC must be closely related to prices in world crude markets. Figure 3 shows that, in fact, ANS prices closely track prices for other widely traded crude oils. The correlation coefficients for ANS and the crude oils shown in Figure 3 each exceed 0.95.

\section{[Figure 3 about here]}

USWC refiners can substitute imported crude oils for ANS. Imported crude oils, like Dubai, are available to USWC refiners at "world prices," i.e., the price struck in Dubai, plus transportation costs to the USWC. Likewise, ANS producers can sell ANS to refiners outside the USWC if export prices justify the additional transportation cost to reach export customers. ${ }^{14}$ Thus world market prices and transportation costs define both a price ceiling, above which West Coast refineries will not pay, and a price floor, below which ANS producers will not sell. The critical question for analysis of the proposed merger, however, is whether the bounds defined by the export and import arbitrage conditions are tight enough to prevent any meaningful exercise of market power.

We can represent the key features of ANS price determination in a dominant-fringe model where $\mathrm{BP}$ is a dominant firm setting USWC prices for ANS within the arbitrage constraints imposed by world crude prices. ${ }^{15}$ This basic market relationship is depicted in Figure 4, which plots the residual demand for ANS on the USWC along with the import and export arbitrage conditions. The import arbitrage condition represents the fact that USWC refineries can and do import substitutes for ANS at the delivered price for imported crude oils, $w$. Similarly, ANS producers can and do export ANS to the Far East or other areas outside the USWC where they receive the world price, $p_{E}$, minus transportation costs, $t .{ }^{16} \mathrm{BP}$ prices on its residual demand curve at the profit maximizing quantity, given world market prices. The marginal cost of selling ANS in USWC markets is the foregone opportunity to sell at world market prices, less the transportation cost of delivering the crude oil to foreign markets. Thus the profit maximizing quantity sold on the USWC, $q^{*}$, is given by the intersection of the export price, minus transportation costs, and the marginal revenue curve. The difference between the fixed ANS supply, $\bar{Q}$, and $q^{*}$ represents ANS that is exported to customers outside the USWC (see Fig. 4).

14 Prior to 1996, ANS producers were prohibited by law from exporting ANS crude oil to foreign countries.

15 The heuristic analysis which follows assumes refiners and BP face arbitrage conditions that are functions of the same price and transportation costs. This assumption is made only for convenience. The economic model can easily be extended to allow different sales and purchase prices on the world market and different transportation costs to import and export crudes. These changes would not alter our econometric model or estimation procedures.

16 ANS exports were prohibited by Federal law until 1996. Prior to 1996, ANS producers "exported" ANS to mid-continental and other U.S. locations. As the transportation costs to these domestic locations are considerably greater than the transportation costs to Far East locations, the export arbitrage price was lower prior to 1996. 
[Figure 4 about here]

The ANS supply curve in Figure 4 is drawn as a vertical line. This representation is consistent with the fact that, for various reasons, ANS is produced at the capacity of existing wells, and therefore ANS output does not vary with the price of ANS over the short and medium run. The econometric implications of this vertical supply curve are discussed further below.

Because refineries can substitute away from ANS, we will never observe the downward sloping ANS demand curve above the import arbitrage condition. Likewise, because ANS producers can sell to alternative markets, we will never observe the downward sloping ANS demand curve at prices below the export arbitrage condition. Thus the effective residual demand for ANS on the USWC that BP perceives is represented by the heavy dotted line in Figure 4. This effective demand curve is what we propose to estimate. ${ }^{17}$

The economic model depicted in Figure 4 implies that the demand for ANS has two distinct regimes. The first regime, characterized by observed purchases along the downward sloping demand curve, corresponds with the time period when the USWC was a net exporter of crude oil. As the USWC moved into deficit, the observed prices and quantities moved up along the downward sloping portion of the demand curve and then back along the horizontal effective demand curve given by the refiners' import arbitrage condition.

The production and consumption data depicted in Figure 1 show that the USWC was no longer a surplus producer of crude oil after about 1992, and from 1996 on the USWC was clearly a net importer of crude oil. Thus we believe the import arbitrage condition has governed the price of ANS on the USWC since around 1996.

An important implication of our economic model is that if the USWC is a net importer of crude oil, BP cannot exercise significant market power because it faces direct competition from imported crude oils, competition wholly unaffected by its merger with ARCO. Estimation of the demand curve allows a direct and powerful test of this implication.

Our review of the existing literature on the demand for crude oil on the USWC did not uncover any previous attempts to directly estimate the elasticity of demand for ANS crude oil. There is, however, a literature on the statistical properties of the price series for various types of crude oil. One question studied in this literature is whether the prices of certain different crude oils are cointegrated. ${ }^{18}$ Two previous studies tested whether the price of ANS is cointegrated with

17 As described in detail below, we estimate the model using total sales of ANS crude oil rather than BP-Amoco's sales. We are able to estimate BP-Amoco's residual demand curve directly from these data because the fringe supply, like BP-Amoco's supply of ANS, is unrelated to short run price variations. Thus BP-Amoco's residual demand curve is equal to the market demand curve minus the observed fringe supply.

18 Cointegrated prices tend to move together. Formally, two nonstationary stochastic processes $x_{t}$ and $y_{t}$ are cointegrated if $x_{t}=\varphi y_{t}+u_{t}$ where $u_{t}$ is a white noise process. The parameter $\varphi$ is called the cointegrating factor. 
various other crude oils traded on the world market. Gülen (1997) and Rodriguez and Williams (1993) both found that ANS is cointegrated with other crude prices.

These cointegration studies are relevant to our analysis for several reasons. First, we are necessarily interested in the statistical properties of our data and have tested whether the price of ANS is cointegrated with the prices of several widely traded crude oils. Second, evidence that prices are cointegrated has been interpreted as an indication that the products in question trade in the same antitrust market. ${ }^{19}$ In particular, the fact that the price of ANS is cointegrated with world crude prices indicates that ANS trades in a world market for crude oil. ${ }^{20}$ This latter point is relevant to our analysis because competition from other crude oils would tend to increase the elasticity of demand for ANS. Thus these prior studies are consistent with our conclusion that the demand for ANS is highly elastic.

Based on our model of ANS prices, we examined the following econometric model of the (inverse) demand function for ANS:

$$
p_{t}=\alpha_{0}+\alpha_{1} A N S_{t}+\alpha_{2} w_{t}+\alpha_{3} R U N S_{t}+\alpha_{4} D E F 96+\alpha_{5} D E F 96 * A N S_{t}+\alpha_{6} D E F 96 * R U N S_{t}+\varepsilon_{t}
$$

The dependent variable is the price of ANS $\left(p_{t}\right)$. The quantitative regressors are ANS sales on the USWC $\left(A N S_{t}\right)$, world crude prices $\left(w_{t}\right)$, and the total quantity of all crude oil consumed in USWC refineries $\left(R U N S_{t}\right)$, a demand shift variable. The $R U N S_{t}$ variable is included to capture variations in the total demand for crude oil on the USWC. As $R U N S_{t}$ increase, we expect the price of ANS to be bid up if ANS is a distinct market. Equation (1) includes a dummy variable for the period when the USWC was a net importer of crude oil, 1996-99, and an interaction term between this dummy variable and ANS sales. ${ }^{21}$ The error term, $\varepsilon_{t}$, is assumed to be i.i.d. with $E\left(\varepsilon_{t}\right)=0$. Starting from this basic econometric model, we explored several alternative specifications and estimation methods. ${ }^{22}$

The coefficients of particular interest are $\alpha_{1}$ and $\alpha_{5}$. The coefficient $\alpha_{1}$ is the slope of the residual demand curve for ANS prior to 1996, and the sum of $\alpha_{1}$ and $\alpha_{5}$ measures the slope of the demand schedule after the USWC became a net importer of crude. It is our hypothesis that

19 Werden and Froeb (1993) review the use of cointegration and other price tests for antitrust market delineation.

20 Rodriguez and Williams (1993) claim to "show that a relevant antitrust product market is no narrower than crude oil and the appropriate geographic market is the world."

${ }^{21}$ Equation (1) allows the both the slope and intercept of the ANS demand curve to change as the USWC moves from surplus to deficit, as predicted by theory. The dummy variable for the deficit period on the USWC is defined $D E F 96=1[t \geq 1996]$ where $1[\bullet]$ is an indicator function that takes the value 1 when the indicated condition is true and 0 otherwise.

22 Specifically, we examined both linear and log-log specifications with various regressors and both IV and OLS estimation methods. 
the sum of these two coefficients is zero, i.e., that the price of ANS was not sensitive to ANS sales on the USWC during the period when the USWC was a net importer of crude oil.

A standard problem encountered when estimating demand curves is the presence of endogenous regressors. Two sources of endogenous regressors are of concern in this model. First, prices of competing goods are often correlated with the contemporaneous errors. ${ }^{23}$ Second, own quantity is typically correlated with the contemporaneous errors. In general, OLS estimation is biased and inconsistent if regressors are correlated with contemporaneous errors. An obvious solution is to use instruments for the endogenous regressors. Our proposed regression model potentially contains both of these typical sources of endogenous regressors.

The proposed model contains the world crude price as a regressor intended to measure the price of competing crude oil. Because ANS comprises less than $2 \%$ of the world crude market, we believe $w$ is effectively exogenous in this regression. It follows that $w$ does not raise any special econometric problems in our regression model. ${ }^{24}$ We followed Hamilton (1994) in testing the validity of this assumption by replacing contemporaneous $w$ with lagged values of $w$ and by including leads and lags of the first difference of the $w$ series as explanatory variables. These tests supported our assumption that $w$ is exogenous.

To address the endogeneity of $A N S$ sales we need a suitable instrument for this regressor. Fortunately, we have an excellent instrument available. We understand that ANS crude oil is effectively produced at full capacity unless prices drop well below historical levels. ${ }^{25}$ Once wells are in place and operational, the marginal cost of continued production is quite low. In addition, there is a danger that reserves will be permanently lost if wells are temporarily shut down. Finally, ANS producers have commitments with the State of Alaska that limit their ability to reduce output. ${ }^{26}$ For all of these reasons, ANS production is not responsive to ANS prices in the short to medium term. ${ }^{27}$ These facts imply that ANS production is independent of the error term

23 By "correlated with contemporaneous errors" we mean that the error associated with the $t^{\text {th }}$ observation is correlated with the $t^{\text {th }}$ period regressors.

24 The literature on residual demand estimation studies the general problem of estimating Marshallian demand curves where the prices of competing goods are an endogenous explanatory variable. Froeb and Werden (1991) contains a useful discussion of this issue. Because $w$ is exogenous in our model, we do not encounter the problems typically associated with estimating Marshallian demand curves.

25 The only exception to this general rule that we are aware of occurs when ANS production is temporarily slowed because (exogenous) logistical problems prevent ANS from being transported to refinery customers. This can occur, for example, if ships are unexpectedly taken out of service or if bad weather limits ship movements.

26 The State of Alaska receives about one-quarter its total revenues from oil-related sources, and three-quarters of its discretionary revenues are from oil-related sources. Fall 1999 Revenue Sources Book, Alaska Department of Revenue, December 8, 1999.

27 The GAO concluded there was still no observable effect on ANS production three years after a sustained increase in the price of ANS. "Alaskan North Slope Oil: Limited Effects of Lifting 
in the demand relationship. ${ }^{28}$ Furthermore, total ANS production is likely to be highly correlated with ANS sales to USWC refiners.

Another potentially endogenous variable is DEF96, which indicates the time when the USWC switched from being a net exporter to net importer of crude oil. In our view it is unlikely this variable is endogenous since the path of ANS crude production is largely exogenous. We address this issue by testing the robustness of the coefficient estimates to different rules for defining the deficit period.

A second econometric issue is that our data are a time series of observations on prices and quantities that may not be stationary. If some or all of the univariate time series are nonstationary, special care must be taken in the specification and estimation of the model to insure that the standard desirable statistical properties apply to the coefficient estimates. Specifically, if the univariate series possess unit roots but are not cointegrated, then OLS (and IV) estimation of the coefficients are biased (Hamilton 1994). Thus, we perform both unit root and cointegration tests on the data.

\section{Data}

We constructed a monthly data series on prices and quantities extending from January 1989 through January 1999 inclusive. We used monthly data for a number of reasons. First, the quantity data were not available on a more frequent basis. Second, because only a limited number of ANS spot market transactions occur each month, the daily ANS price series may suffer from measurement error. Third, shipping times from foreign crude sources are about one to two months. ${ }^{29}$

We calculated the monthly average price for ANS from daily spot market prices as reported by Reuters. A real monthly price series was then constructed using the quarterly GDP deflator. These deflated data were used to measure the price of ANS in our analyses.

The price of West Texas Intermediate (WTI) is our primary proxy for the world price of crude oil, w. WTI is the benchmark crude oil watched most closely in the United States. It is thickly traded on the New York Mercantile Exchange (NYMEX) and the prices for many crude oils,

Export Ban on Oil and Shipping Industries and Consumers," United States General Accounting Office, GAO/RCED-99-191, July 1999.

28 The independence between ANS production and the error term potentially could be violated if ANS production capacity were a function of the price of ANS. We understand that ANS production capacity is not responsive to the price of ANS (including both the price of ANS on the USWC and the price of ANS outside the USWC, e.g., the price of ANS in the Far East). Instead, ANS production capacity is driven by well technology.

29 Purchases of ANS crude typically take place approximately one month prior to delivery. Purchases of crudes from more distant sources, such as Saudi Arabia, typically take place two or more months prior to delivery. However, crudes from all locations are sometimes available for delivery over shorter time spans, depending on transportation and storage logistics, short run fluctuations in refinery demand, and producer marketing decisions. 
including ANS, are frequently quoted as deviations from the price of WTI. We calculated the monthly average price for WTI from NYMEX daily closing prices. These data were also deflated using the quarterly GDP deflator for our analyses. We also estimated the model using real monthly average prices for Arab Light, Arab Medium, West Texas Sour, and Brent as alternative proxies for the world price of oil and found these alternative price measures did not substantively effect our results.

We also estimated the model including both $w_{t}$ and $w_{t-1}$. The rationale for including a oneperiod lag of the world crude price in the estimated equation is that because the reported ANS price is based on only on a few transactions per month, the ANS price potentially could be better explained by the previous month's WTI price, if ANS sales predominantly take place early in the month. Including $w_{t-1}$ in the regressors did not affect the qualitative results.

The quantity of ANS sold to USWC refiners can be accurately measured from U.S. Maritime Administration data on shipments since all ANS that leaves Alaska does so by ship, and the ANS that does not leave the state is consumed by in-state refineries. ${ }^{30}$ Our ANS sales data measure the volume of shipments departing Valdez for the USWC.

One issue to consider for the sales data is the timing of the relationship between ANS and $p$. In the spot market for ANS, the ANS-WTI price differential is negotiated roughly one month prior to delivery, and the relationship between $p$ and $A N S$ is determined at the time the differential is negotiated. In principle, one should attempt to match up ANS prices with the quantities that correspond to each transaction. We believe that the data on shipments leaving Valdez match the timing of the price data reasonably closely. To explore this issue, we estimated regressions run separately on both $A N S_{t}$ and $A N S_{t-1}$. Our results are not sensitive to the choice of $A N S$ timing.

We used U.S. Department of Energy data on the total quantity of crude oil consumed on the USWC as a measure of the total demand for crude oil on the USWC. If the total quantity of crude oil consumed each month varies with the price of ANS, then this variable is endogenous. We understand, however, that USWC refineries have a limited output response to changes in the world price of crude oil and no response to changes in the price of ANS taken separately. Thus we believe the $R U N S_{t}$ data are exogenous.

We used total ANS production as reported by the State of Alaska as an instrument for ANS sales to USWC refineries. These two variables are highly correlated ( $\rho=0.796)$, suggesting that crude production is a good instrument for sales. One and two-period lags of $p$, together with all of the exogenous variables, were also included in the list of instruments.

We additionally note that our estimating equation contained a dummy variable for the year 1991 . The 1991 Iraq-Kuwait War was a singular event that had a profound influence on the world market for crude oil. The war's effects were felt on both the supply and demand sides of the market. On the supply side, the war precipitated a shock due to the loss of Kuwaiti and Iraqi crude oils that caused crude oil prices to double in a few months time. On the demand side, the

30 There is a small amount of pipeline loss that is also accounted for in the data. 
loss of the Kuwaiti refineries reduced the demand for sour crude oils relative to sweet crude oils because the Kuwaiti refineries processed relatively more sour crude than other refineries. Furthermore, the increased demand for jet fuel further tipped world demand toward light, sweet crude oils. This shift in demand was reflected in a widening of the sweet-sour price differential. The dummy variable for 1991 is included to control for these unusual events.

\section{Results}

The first task in the analysis is to test for the existence of unit roots in the real price series for $p$ and $w .{ }^{31}$ The Augmented Dickey-Fuller (ADF) test for a unit root fails to reject the null hypothesis of a unit root for each price series at the $10 \%$ level. ${ }^{32}$ An ADF test on the first differences of each price series rejects the null at the $1 \%$ level. Thus, we treat each price series as integrated of order one ${ }^{33} \mathrm{We}$ also examined the stationarity of $A N S$ and concluded that it does not have a unit root. ${ }^{34}$

We next tested whether $p$ and $w$ are cointegrated. Unless these non-stationary price series have a common cointegrating factor, standard estimation methods can generate spurious results Hamilton (1994). The test results reject the hypothesis of no cointegration at the 5\% level. ${ }^{35}$ The cointegrating coefficient is approximately equal to one.

It is also important to note that coefficient estimates from cointegrating regressions may not have asymptotic distributions that are Normal (Hamilton (1994). This result has implications for hypothesis testing. We discuss this point further below.

${ }^{31}$ Consider an $A R(1)$ process $x_{t}=\rho x_{t-1}+u_{t}$. This process is said to have a "unit root" if $\rho=1$.

32 The test statistics are -3.427 and -3.372 , and the $10 \%$ critical value is -3.510 . We performed the test with an intercept term, a time trend, a break in the series in 1996, and four lags. The test methods and critical values for stochastic processes with an exogenous break are described in Perron (1989). We also performed the unit root tests without a break in 1996. The test statistics are -3.046 and -2.929 for $p$ and $W T I$ respectively, and the $10 \%$ critical value is -3.149 . We performed these tests with an intercept term, a time trend, and four lags. Excluding the trend did not change the conclusions regarding the null of a unit root.

${ }^{33}$ A variable that is nonstationary in levels, but stationary in first differences, is described as integrated of order one.

${ }^{34}$ The test statistic is -4.417 , and the $1 \%$ critical value is -4.039 . We performed this test with an intercept, a linear deterministic time trend, and four lags.

35 We used the Johansen cointegration test and included an intercept and a linear trend in the cointegrating equation. For the full sample, January 1989 through January 1999, the test failed to reject the null of no cointegration at the $5 \%$ level. However, we believe that this failure to reject is due to the presence of a break in the ANS price series in 1996. To explore this hypothesis, we performed cointegration tests on two subsamples of the data: 1989-1995 and 1996-1999. The Johansen test on these two subsamples rejected the null hypothesis of no cointegration at the 5\% level. This result is consistent with the previous studies that found the price of ANS was cointegrated with the price of WTI. Gülen (1997) and Rodriguez and Williams (1993). 
Table 2 presents parameter estimates using IV and OLS estimation. The coefficient estimates on the variables of interest $-\alpha_{1}$ and $\alpha_{5}$ - are similar. Our comments will focus on the IV results, which are presented in column (1). The reported standard errors are Newey-West (1987) heteroskedasticity and autocorrelation consistent (HAC) standard error estimates.

The specification in equation (1) produces two slope coefficients corresponding to the pre- and post-deficit periods on the USWC. The coefficient estimate for the pre-deficit period, -0.010 , is significantly different from zero at the $1 \%$ level. This coefficient implies that the market price elasticity of demand for ANS at a price of $\$ 16.85$ per barrel and ANS sales to USWC refiners of $1,356 \mathrm{MBD}$ is -0.8 in the pre-deficit period. ${ }^{36}$ The coefficient estimate for the post-deficit period is equal to the sum of the coefficient estimates for $A N S_{t}$ and $D E F 96^{*} A N S_{t}$. This coefficient, 0.002 , is insignificantly different from zero. ${ }^{37}$ Our interpretation of this coefficient estimate is that the import arbitrage condition holds in the post-deficit period, and consequently, the market elasticity of demand for ANS is exceptionally high. ${ }^{38} \mathrm{We}$ also examined alternative regressors that allowed the kink in the demand curve to appear in early 1994, early 1995, and mid-1995, with no material effect on the results. ${ }^{39}$ The coefficient estimates also reflect the long-run cointegrating relationship between $p$ and $w$, as the coefficient on $w$ is close to one.

We can now readily calculate an estimate of the price elasticity of demand along BP's residual demand curve. It is easy to show, given our assumption of an inelastic fringe supply, that BP's firm-specific elasticity is equal to the market elasticity multiplied by the inverse of BP's share of ANS sales. At the time the merger was announced, BP's share of ANS sales was approximately $40 \%$. Thus the elasticity of the residual demand for ANS that BP observed at the time of the merger was more than twice the (already highly elastic) market demand for ANS. ${ }^{40}$

One important interpretative question is whether the parameter estimates from the regressions reported in Tables 1 are long run or short run values. We are inclined to think of the estimates as long run elasticities because most of the variation in ANS sales comes from the long run trend

36 The mean values of $p$ and $A N S$ are $\$ 16.85$ and 1,356 MBD respectively.

37 The standard error estimate for this coefficient is 0.004 ; the $p$-value is 0.532 .

$38 \mathrm{We}$ also examined refinery specific substitution patterns and found evidence that refiners on the USWC use a variety of imported crude oils and regularly substitute these for ANS when relative prices warranted the change. Our econometric findings were strongly supported by this detailed evidence of import substitution.

39 Specifically, we replaced $D E F 96$ with the following alternative dummy variables DEF $94 \equiv 1[t \geq 1994]$, DEF $95 \equiv 1[t \geq 1995]$ and $D E F 955 \equiv 1[t \geq 1995: 06]$.

40 We also examined differences in the substitution patterns of firms with captive ANS production, such as ARCO and Exxon, and firms with no ANS production. These data showed that captive producers were slower to substitute than were merchant market customers. The estimates that we report here do not account for these differences in substitution patterns. Since all of BP's sales went to merchant customers, the elasticity that BP actually observed was in all likelihood greater than indicated by the estimates we report here. 
toward reduced ANS production. ${ }^{41}$ There are short run movements in ANS sales, but these are small in comparison to the more than $40 \%$ decline in ANS production over the observation period. ${ }^{42}$ Furthermore, the long run trend in ANS production was projected well in advance, and USWC refiners made investment and crude oil purchase decisions with the decline in mind. Thus the data are dominated by the adjustments refineries made in response to the anticipated decline in ANS production.

As mentioned above, the asymptotic distributions of the coefficient estimates from a regression on cointegrated variables may not be Normal. Specifically, if the error terms in the univariate process of $w_{t}$ are correlated with the error term in the regression equation, standard distribution theory may not hold. One can test for the presence of such correlation by adding leads and lags of $\Delta w_{t}$ to the regression equation (Hamilton 1994). This was done and the qualitative findings were not affected. In addition, we examined the correlations between the residuals from the regressions and the residuals from autoregressions on $w_{t}$ and $A N S_{t}$. These correlations were small, indicating that standard distribution theory applies. ${ }^{43}$

The results reported in Table 2 are robust to alternative regressors and specifications. As noted in our discussion of the data, we examined a number of alternative regressors and found they did not have a substantive effect on our results. In addition, we estimated a log-log specification of the model which produced results that were not materially different from those reported here. ${ }^{44}$

Finally, we also estimated a demand relation (i.e. ANS quantity is the dependent variable and ANS price is a regressor) as opposed to the inverse demand relationship we report in Table 2. Table 3 presents IV estimates of this specification using ANS production as the instrument for price. As with our other robustness tests, the estimated demand elasticities are very close to those implied by the parameter estimates in Table 2 . In the pre-deficit regime, the estimated elasticity

41 See Froeb and Werden (1990) for a similar interpretation of elasticity estimates from a regression equation.

42 Alternatively, one could argue that since a cointegrating relationship is a long run relationship, we should think of these as long run estimates.

43 Specifically, we examined $\operatorname{corr}\left(\varepsilon_{t}, \mu_{t}\right)$ and $\operatorname{corr}\left(\varepsilon_{t}, v_{t}\right)$ where $\mu_{t}$ and $v_{t}$ are the errors from the following autoregressions:

$$
\begin{aligned}
& W T I_{t}=\gamma_{0}+\gamma_{1} W T I_{t-1}+\gamma_{2} W T I_{t-2}+\gamma_{3} W T I_{t-3}+\mu_{t}, \text { and } \\
& \text { PROD }_{t}=\lambda_{0}+\lambda_{1} \text { PROD }_{t-1}+\lambda_{2} \text { PROD }_{t-2}+\lambda_{3} P R O D_{t-3}+v_{t}
\end{aligned}
$$

where $P R O D_{t}$ is ANS production, the instrument for $A N S_{t}$. The correlations were -0.193 and 0.052 respectively.

${ }^{44}$ Detailed results of these alternative estimates are available from the authors. 
of demand is -0.9 , and in the post-deficit period the estimated relationship is positive and insignificant. 45

\section{Conclusion}

In this paper we estimated the demand relation for ANS crude oil sold to refiners on the USWC. Our estimates show that the market demand for ANS crude oil was inelastic in the early part of the 1990s, when the region was a net exporter of crude oil, but demand became highly elastic in the latter half of the decade, when the region became a net importer of crude oil. In the latter half of the 1990s, an import arbitrage condition has prevented the price of ANS from exceeding world price levels. These estimates indicate that the proposed BP/ARCO merger would not have created or enhanced market power over ANS prices.

We regret to report that these findings had little or no impact on the outcome of the FTC's review of the proposed merger of $\mathrm{BP}$ and ARCO. The consent decree signed by the FTC and BP/ARCO required the merging parties to divest ARCO's ANS holdings. Our findings suggest this divestiture was unnecessary to ensure competitive pricing of Alaskan crude oil on the U.S. West Coast. While we pointed out that ANS prices are now governed tightly by competition with imports, the FTC seemed fixated on the fact that ANS prices were lower (relative to world crude oil prices) a decade ago, when the West Coast was a net exporter. The FTC appeared to believe that preserving ARCO independently from BP might, somehow, cause those lower prices to reappear. We stressed that the lower prices would only arise if the West Coast again became a net exporter, which would not happen without a truly huge new find in Alaska. Even then, the merger would not tend to raise prices, so long as a company other than ARCO could exploit the new reserves found on the North Slope. Sadly, we see this as a case where fairly straightforward economics - an increase in the price when a region moves from exporting to importing a commodity, with import competition determining the price now and in the future, all confirmed by careful empirical analysis — was ignored by the Federal Trade Commission.

45 Monte Carlo studies have shown evidence of small sample bias in cointegrated regressions, and further, the bias is inversely related to $R^{2}$. This fact suggests we should put more faith in the specification with the higher $R^{2}$. Our analysis shows that the price regressions have much higher $R^{2}$ than the quantity regressions -0.95 for the price regression as compared to 0.53 for the quantity regression. 


\section{References}

Baker, J. and D. Rubinfeld (1999) "Empirical Methods in Antitrust Litigation: Review and Critique," American Law and Economics Review, 1(2): 386-435.

Gürcan Gülen, S. (1997) "Rationalization in the World Crude Oil Market," The Energy Journal, $109-126$.

Froeb, L. and G. Werden (1990) "Market Delineation under the Merger Guidelines: The Role of Residual Demand Elasticities,” US Dept. of Justice, EAG Working Paper 90-3.

Froeb, L. and G. Werden (1991) "Residual Demand Estimation for Market Delineation: Complications and Limitations," Review of Industrial Organization, 6: 33-48.

Hamilton, J. (1994) Time Series Analysis, Princeton, NJ: Princeton University Press.

Newey W. and K. West (1987) "A Simple Positive Semi-Definite, Heteroskedasticity and Autocorrelation Consistent Covariance Matrix," Econometrica, 55: 703-708.

Perron, P. (1989) "The Great Crash, The Oil Price Shock, and The Unit Root Hypothesis," Econometrica 57: 1361-1401.

Rodriguez, A.E. and M. D. Williams (1993) 'Is the World Oil Market 'One Great Pool'? A Test," Energy Studies Journal, 121-130.

Slade, M (1985) "Exogeneity Tests of Market Boundaries Applied to Petroleum Products," Journal of Industrial Economics, 34(3): 291-303.

Spiller, P.T. and P. Huang (1986) "On the Extent of the Market: Wholesale Gasoline in the Northeastern United States," Journal of Industrial Economics, 35(2): 131-145.

Stigler, G.J. and R. A. Sherwin (1985) "The Geographic Extent of the Market," Journal of Law and Economics, 28(3): 555-586.

Werden G. and L. Froeb (1993) "Correlation, Causality, and All That Jazz," Review of Industrial Organization, 8: 329-353. 
Table 1

Refinery Runs and Capacity at Selected Refineries on the U.S. West Coast

\begin{tabular}{|c|c|c|c|c|c|c|c|}
\hline Location & Refineries & & 1994 & 1995 & 1996 & 1997 & 1998 \\
\hline Puget Sound & $\begin{array}{c}\text { Arco } \\
\text { Equilon } \\
\text { Tesoro } \\
\text { Tosco } \\
\text { U.S. Oil }\end{array}$ & $\begin{array}{r}\text { Runs } \\
\text { Capacity }\end{array}$ & $\begin{array}{l}531 \\
550\end{array}$ & $\begin{array}{l}548 \\
564\end{array}$ & $\begin{array}{l}572 \\
572\end{array}$ & $\begin{array}{l}573 \\
580\end{array}$ & $\begin{array}{l}556 \\
580\end{array}$ \\
\hline Los Angeles & $\begin{array}{c}\text { Arco } \\
\text { Chevron } \\
\text { Equilon } \\
\text { Mobil } \\
\text { Tosco } \\
\text { Ultramar }\end{array}$ & $\begin{array}{r}\text { Runs } \\
\text { Capacity }\end{array}$ & $\begin{array}{l}833 \\
877\end{array}$ & $\begin{array}{l}846 \\
880\end{array}$ & $\begin{array}{l}833 \\
922\end{array}$ & $\begin{array}{l}826 \\
922\end{array}$ & $\begin{array}{l}869 \\
952\end{array}$ \\
\hline San Francisco Bay & $\begin{array}{l}\text { Chevron } \\
\text { Equilon } \\
\text { Exxon } \\
\text { Tosco }\end{array}$ & $\begin{array}{r}\text { Runs } \\
\text { Capacity }\end{array}$ & $\begin{array}{l}741 \\
746\end{array}$ & $\begin{array}{l}688 \\
794\end{array}$ & $\begin{array}{l}729 \\
766\end{array}$ & $\begin{array}{l}722 \\
768\end{array}$ & $\begin{array}{l}698 \\
779\end{array}$ \\
\hline & & $\begin{array}{r}\text { Total Runs } \\
\text { Total Capacity }\end{array}$ & $\begin{array}{l}2105 \\
2173\end{array}$ & $\begin{array}{l}2081 \\
2237\end{array}$ & $\begin{array}{l}2133 \\
2259\end{array}$ & $\begin{array}{l}2121 \\
2269\end{array}$ & $\begin{array}{l}2123 \\
2310\end{array}$ \\
\hline $\begin{array}{r}\text { Tota } \\
\text { Total C } \\
\end{array}$ & $\begin{array}{l}\text { uns, All US } \\
\text { city, All US }\end{array}$ & $\begin{array}{l}\text { WC Refineries } \\
\text { WC Refineries }\end{array}$ & $\begin{array}{l}2601 \\
2927 \\
\end{array}$ & $\begin{array}{l}2526 \\
2997 \\
\end{array}$ & $\begin{array}{l}2554 \\
3025 \\
\end{array}$ & $\begin{array}{l}2545 \\
2932 \\
\end{array}$ & $\begin{array}{l}2536 \\
2973 \\
\end{array}$ \\
\hline
\end{tabular}


Table 2

IV and OLS Coefficient Estimates of the Inverse Demand for ANS

\begin{tabular}{|c||c|c|}
\hline Variable & $\begin{array}{c}\text { IV Estimates } \\
\text { (standard errors) } \\
(\mathbf{1})\end{array}$ & $\begin{array}{c}\text { OLS Estimates } \\
\text { (standard errors) } \\
\text { (2) }\end{array}$ \\
\hline \hline \multirow{2}{*}{ Constant } & 2.875 & -2.310 \\
& $(4.760)$ & $(3.427)$ \\
\hline \multirow{2}{*}{$A N S_{t}$} & -0.010 & -0.002 \\
& $(0.003)$ & $(0.001)$ \\
\hline \multirow{2}{*}{ DEF96 } & -7.364 & -3.448 \\
& $(6.006)$ & $(5.136)$ \\
\hline \multirow{2}{*}{ DEF96*ANS } & 0.012 & 0.007 \\
& $(0.004)$ & $(0.002)$ \\
\hline \multirow{2}{*}{$w_{t}$} & 0.981 & 0.945 \\
\multirow{2}{*}{$R U N S_{t}$} & $(0.029)$ & $0.023)$ \\
\hline \multirow{2}{*}{ DEF96* RUNS } & 0.003 & 0.001 \\
& $(0.002)$ & $(0.001)$ \\
\hline \multirow{2}{*}{1991} & -0.003 & -0.002 \\
& $(0.002)$ & $(0.002)$ \\
\hline$R^{2}$ & -0.931 & -1.521 \\
$N$ & $(0.460)$ & $0.260)$ \\
\hline Durbin-Watson & 0.95 & 0.97 \\
& 119 & 0.89 \\
\hline
\end{tabular}


Table 3

IV Coefficient Estimates of ANS Demand.

(dependent variable is ANS shipped to USWC)

\begin{tabular}{|c||c|}
\hline Variable & $\begin{array}{c}\text { IV Estimates } \\
\text { (standard errors) }\end{array}$ \\
\hline \hline \multirow{2}{*}{ Constant } & 563.79 \\
& $(285.45)$ \\
\hline \multirow{2}{*}{$p_{t}$} & -70.41 \\
& $(25.44)$ \\
\hline \multirow{2}{*}{ DEF96 } & 96.44 \\
& $(200.13)$ \\
\hline \multirow{2}{*}{$D E F 96^{*} p_{t}$} & 207.60 \\
& $(120.89)$ \\
\hline \multirow{2}{*}{$W T I_{t}$} & 71.04 \\
\multirow{2}{*}{$D E F 96^{*} W T I_{t}$} & $(23.50)$ \\
\hline \multirow{2}{*}{$R U N S_{t}$} & -200.61 \\
\multirow{2}{*}{1991} & $(120.63)$ \\
\hline$R^{2}$ & 0.25 \\
$N$ & $(0.11)$ \\
\hline Durbin-Watson & -42.40 \\
& $(53.86)$ \\
\hline
\end{tabular}




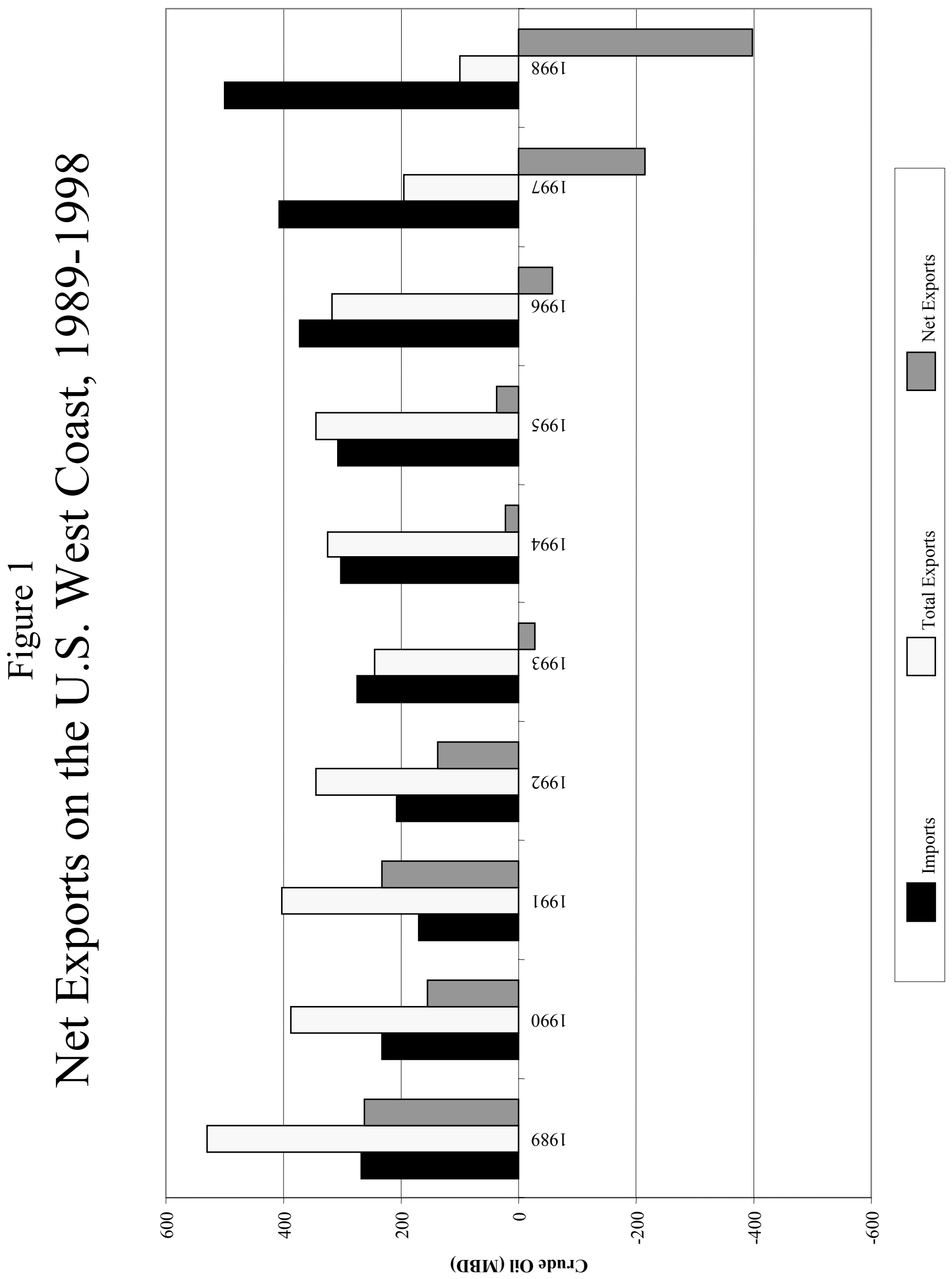




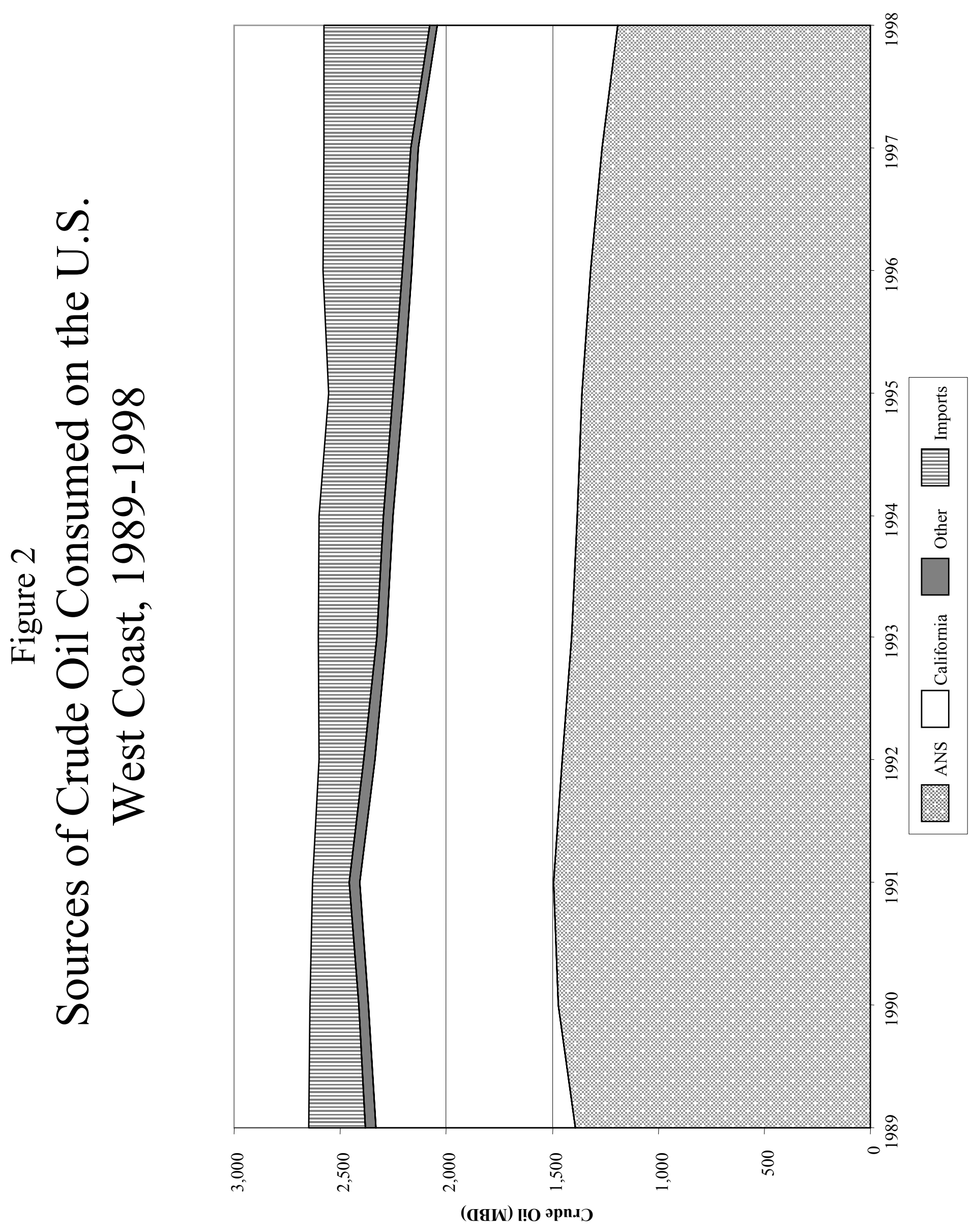




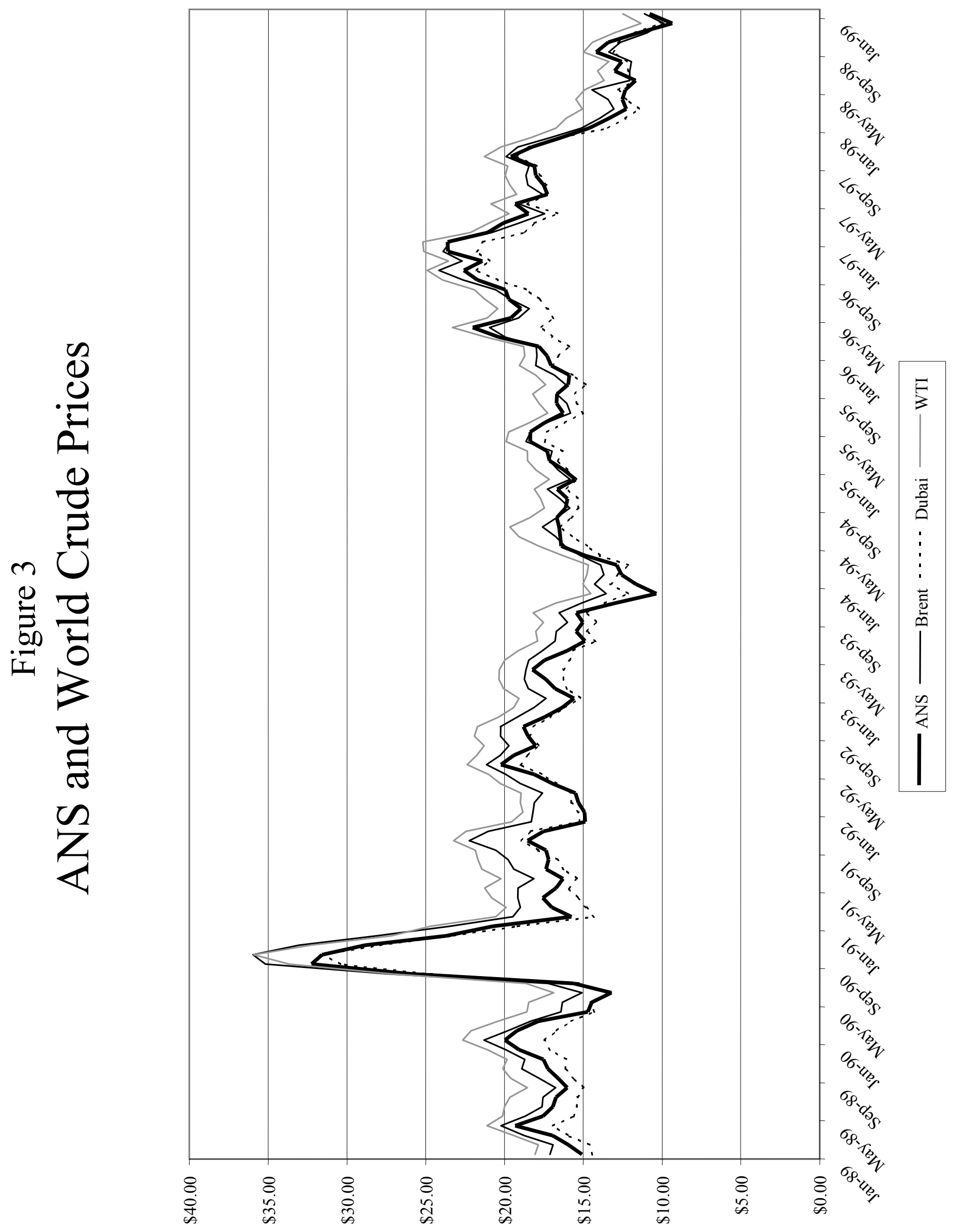




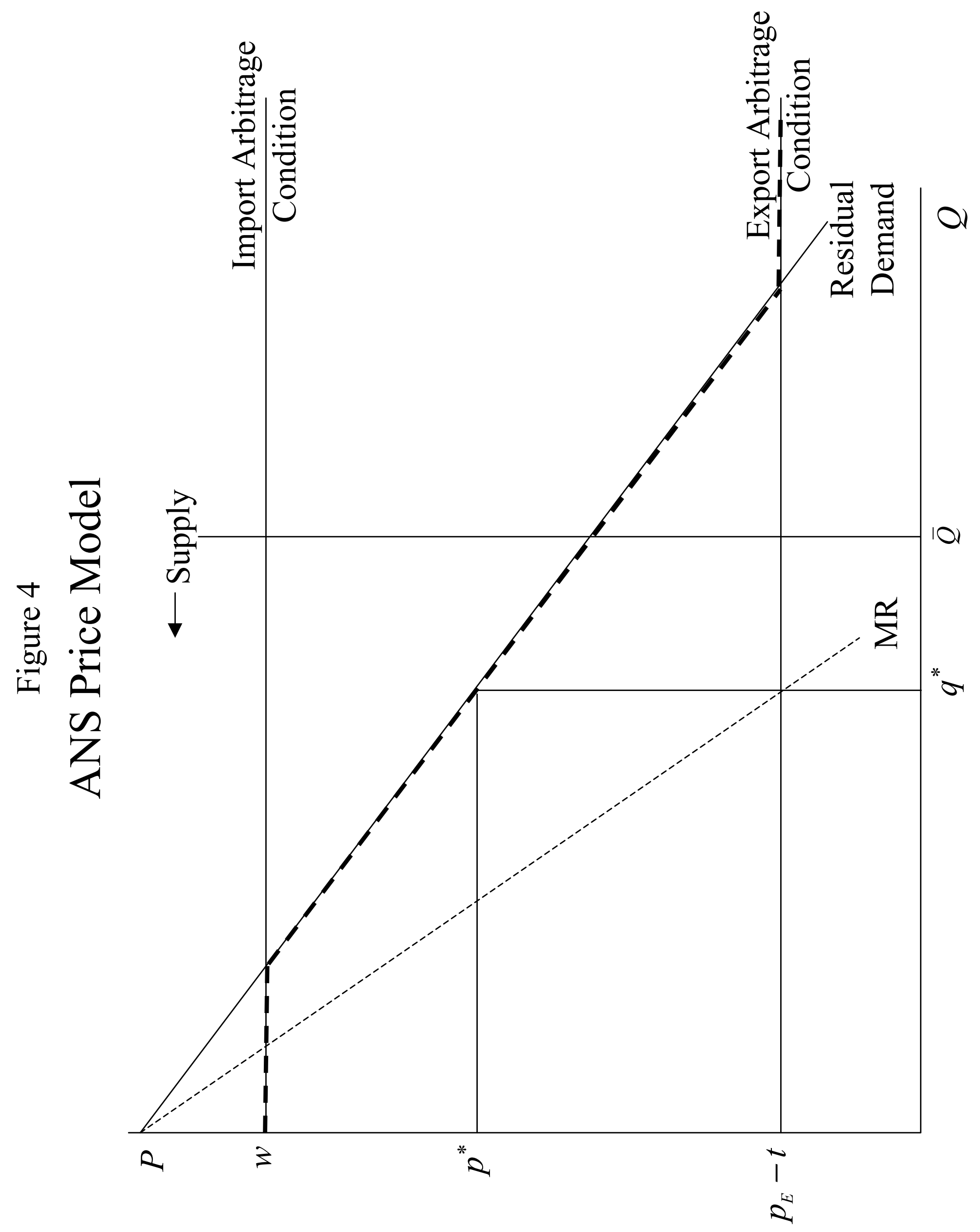

